\title{
An overview on floral diver sity of Arawali forest: A potential source for natural dyes
}

\section{Dolly M ogra}

Department of Textile and Apparel Designing, College of Home Science, Maharana Pratap University of Agriculture and Technology, Udaipur (Rajasthan), INDIA

E-mail: dollymogra@gmail.com

Received: April 13, 2013; Revised received:J une 29, 2013; Accepted: August 16, 2013

Abstract: The present study presents an overview on floral diversity and identifies Non-timber Forest Products (NTFP) that can be used as Natural Dye sources in textile sector. This was a descriptive study; Historical, as well as current data was collected through surveys and interviews. Individual and focus group interviews with tribal members were conducted to gather information regarding details of forest proximity. This collective study indicates that the Aravalli hill ranges constitute the most dominant hilly area of Rajasthan. Most of the forests are over the hilly areas i.e. in Udaipur, Rajasamand, Kota, Baran Sawai Madhopur, Chittorgarh, Sirohi, Bundi, Alwar, Jhalawar and Banswara districts, which make up for about 50 per cent of the forests of the state. Khakara, semal, rohida, gadha palash, mokha, marod phalli, davai, van gulab etc. are identified as red chroma, amaltash, awla, gundhi, babool etc.are identified as yellow and related chroma. Forests are major components of the earth's natural resources and they are increasingly critical to the welfare of the economy, environment, and population. Gum products, starch products, antimicrobial resources, paper industry products may be collected from hilly forest areas and can be easily adopted at cottage level for gainful employment of tribal women.

Keywords: Eco friendly, Forests, Sustainable economic growth, Tribal woman

\section{INTRODUCTION}

Rajasthan has exhibited spectacular progress in several areas like agricultural production, harnessing of mineral resources, development of transport and communication, and the production of energy resources but the rate of progress and plans of economic development have slowed to a large extent by a parallel growth of human population and livestock (Chauhan, 2008). Human resources are, therefore, to be geared into the channel of economic progress while taking care to arrest their future growth rate. Forests are one of the important natural resources so far as environmental protection and ecological balance are concerned. In Rajasthan only 9.49 per cent of the total geographical area of the State (4.19\% of the country) is classified as forest area (3261984.314 Hectares), The Aravalli Mountains, which crosses the state of Rajasthan diagonally for a distance of about 800 km(DES, 2009).

As noted in the Forest Survey of India (2011), the forests are unevenly distributed in the various districts. Most of the forests are over the hilly areas i.e. in Udaipur, Rajsamand, Kota, Baran, Sawai Madhopur, Chittorgarh, Sirohi, Bundi, Alwar, Jhalawar and Banswara districts. In addition providing invaluable ecological services for the environmental security to the nation, forest also contribute significantly to economy especially that of rural and marginalized strata of the society. Forests and trees outside forests are rich sources of timber, firewood, bamboos, fodder and Non Timber Forest Products (NTFP) and at the same time they provide employment opportunity to a large section of the tribal and other disadvantageous rural communities.

NTFPs include medicinal plants, mushrooms, fruits, resins, bark, roots and tubers, leaves, flowers, seeds, honey etc. NTFPs can be "any commodity obtained from the forest that does not necessitate harvesting trees, including bush meat, fur-bearing animals and the gathering of deadfall fuel wood" (MFR, 2008). Hegde (2005) also highlights the importance of NTFPs for the purposes of food security; wood and biomass; medicines and plant protection; as well as aromatics, dyes and oilseeds.

The local economy and livelihood of the tribal people and non-tribal people living in southern well- forested region of Rajasthan, is dependent on agriculture, livestock rearing, horticulture and occasional (seasonal) migration to urban areas for unskilled labour work (Vyas, 2008). He further suggests that NTFP should be considered a 'magic bullet' to solve the problems of deforestation. He also states that NTFP are important, everlasting, and a fundamental part of tribal culture, and 
must be considered in forest management decisions. Cultivating trees for NTFPs also helps in achieving environmental objectives such as the conservation of watersheds, biological diversity, and genetic resources (Tejaswi, 2008).

The rich wealth of non-renewable resources is yet to be explored and exploited (Pokharna, 1997). Their judicious exploitation can make the state economically selfsufficient (RAMB, 2012). The forests of Rajasthan cover an area of 32,638.74 sq km which is $9.54 \%$ of the total geographical area of the state (EAMF, 2012). Laxmi et al. (2003) and Robbins et al. (2009) document the dependence of rural people on the forest for fuel wood. Forests not only meet fuel wood and fodder needs of the people and livestock, but also contribute Rs. 7,160 million (\$14.09 million $\mathrm{CAD}$ ) to the state domestic products. Tribal people and forests have a long history together (Vyas, 2008). These people have depended on forest for economic, social and cultural needs (Tejaswi, 2008). Forestry research needs to be strengthened towards desired goals of higher productivity, technology improvement and cost effectiveness in forestry practices. The forest also provides medicinal plants that are not only effective at treating a range of ailments, but are also sacred to tribal culture and heritage (Jena, 2000).

A woman is like a pivot around which the family, the society and the whole community move. These women are born and bred to the tradition of work and are a real symbol of dedication, patience and sacrifice. The tribal women are more near to nature; most of the requirements of family are fulfilled by forest products. Many tasks like collecting wood, other materials of livelihood, grazing animals are regular tasks performed by female. But due to ignorance they were unaware about the economic and ecological importance of many natural products and resources; it is prime need to encourage and trained tribal women towards collecting, drying and giving commercial look to unexplored natural products in economic enrichment (Chouhan, 2007) Besides this, fabric enrichment techniques like printing, dyeing etc. by natural dyes can also be popularised among tribal women to utilize their leisure time (NAIP, 2011). In order to strengthen tribal female folk, the present research was carried out with the objectives viz. to enlist plants, trees available in Arawali forests, to enlist natural sources used in eco friendly dyeing of textiles and to enlist the constraints faced by tribal female folk.

\section{MATERIALS AND METHODS}

Trees and plants related to natural dyes and products used in textile industries were identified and enlisted available in forest area of Rajasthan. Along this the constraints faced by tribal female folk of hilly areas of Udaipur region were discussed and concluded.
Unstructured interview technique was administered for data collection on 60 respondents of hilly areas of Udaipur Region. Tribal women, men, forest employees as primary sources and books, literature, internet websites, search engines were used as secondary and tertiary sources.

\section{RESULTS AND DISCUSSION}

Forests represent an abundance of life by providing a habitat for many forms of plants and animals (Schmithusen and Klaus, 2000). In Table 1 the list of plants and trees is tabulated with botanical and Hindi name that has importance in ecology and economy.

The contemporary textile processing industry is seeking more and more inquiries regarding "dyeing with natural dyes" and therefore the subject of natural colours has assumed a great significance. An increasing realization, that the intermediates and chemicals of synthetic dyes are toxic and hazardous to human health as well as to environment, has led to the revival of interest in the non toxic eco friendly colouring materials (Mogra, 1999). Researches show that tannin present in babool bark may be successfully used for dyeing leather.

Natural Dyes: Colour is such a vital and vibrant ingredient of our existence and has played an important part in adding beauty to the world. Natural dyes comprise those colorants that are obtained from animal or vegetable matter without chemical processing (Upadhyay and Choudhary, 2012). These are non - pollutant, non-allergic, biodegradable and generally have a better compatibility with the environment. These are extracts from the roots, bark, leaves, and flowers of fruits of different herbs, shrubs and trees.

There are so many investigations by various scientists but a lot still remains to be explored and utilized by the tribal women. The technical bulletin of All India Coordinated Research Project, Clothing and Textile revealed one of the crucial finding that although natural dye sources were available in all the forests, yet they were hardly utilized and collected for commercial purpose (Shrivastava, 2006). Hence technologies for dyeing and printing with natural dyes need to be developed immediately like Germany which preferred only ecofriendly dyed fabrics. Natural dyes produce a wide range of excellent soft lustrous colours with different mordant, it would become stable income generating source for tribal women with great scope in upcoming years. Ray (2008), in his research on resource management in Rajasthan, studied the impact of an institutional approach in resolving environmental crises. One powerful way of understanding environmental issues, such as deforestation, is to examine the changing structure of communities in the area (Moran, 2005).

The consumers now consider three factors as important criteria, while selecting textiles. These are (1) Aesthetics 
Table 1. List of plants and trees found in Arawali forests.

\begin{tabular}{|c|c|}
\hline Botanical name & Hindi name \\
\hline Acacia catechu & Kher \\
\hline A. ferrugenia & Kheger \\
\hline A. nilotica & Babool \\
\hline A. senegal & Kumatha \\
\hline A. leucophloea & Ronz \\
\hline Haldina cordifolia Syn. Adina cordifolia & Haldu \\
\hline A egle marmelos & Bhel \\
\hline Ailanthus excels & Aradu \\
\hline Alangium salvifolium & Akol \\
\hline Albi zia lebbeck & Sirus \\
\hline A. odoratissima & Kala Sirus \\
\hline A. procera & Safed sirus \\
\hline Anogeissus latifolia & Dhawad \\
\hline A. pendula & Dhok \\
\hline Anthocephalus chinensis & Kadhamb \\
\hline Azadirachta indica & Neem \\
\hline Bauhinia racemosa & Koiral, Kanchan \\
\hline B ombax ceiba & Semal \\
\hline Boswell ia serrate & Salar \\
\hline Buchanania Ianzan & Achar (chiroli) \\
\hline Butea monosperma & Khakara \\
\hline Cassia fistula & Amaltash (karmela) \\
\hline Crateva magna & Barna \\
\hline Dalbergia latifolia & Sheesham (rose wood, kala sheesham) \\
\hline D. paniculata & Dhoban \\
\hline D. sissoo & Sheesham \\
\hline Dendrocala mus strictus & Bans \\
\hline Delonix elata & Sandeshda \\
\hline Derris indica & Kadanj, karanj \\
\hline Dichrostachys cinerea & Emna (bilatari) \\
\hline Diospyros melanoxylon & Timaru (tendu) \\
\hline D. M ontana var.cordifolia & Bistand \\
\hline Ficus benghal ensis & Bad, baragad \\
\hline Fitc us recemosa & Aman, goolar \\
\hline Feronia Limonia & Kotpadi, kainth \\
\hline Erythrina suber osa & Gadha palash \\
\hline Ficus religious & Peepal \\
\hline Garuga pinnata & Karpata \\
\hline Gmelina arborea & Havan, sevan \\
\hline Grewia teliafolia & dhaman \\
\hline Holoptelia integrifolia & Churel \\
\hline Hymenodicty on & Lunkhera, lunia \\
\hline Lager stroemia & kaliharia \\
\hline Lannea Coromandelica & Gothal \\
\hline Maduluca Longifolia & Mahua \\
\hline M angifer a indica & Aam \\
\hline Miliusa tomentosa & Umbia \\
\hline
\end{tabular}


Table 1. Contd.

\begin{tabular}{lc}
\hline Ougenia dalbergeoides & \\
Phyllanthus embica & Tanas, tinsa \\
Prosopi s embica & Awla \\
M arsupium & Khejadi \\
Salvadora oleoides & Bija \\
Santalum album & Pilu \\
Soymida febrifuga & Chandan \\
Sterculia urens & Rohan \\
Sterospermum & Kadaya \\
Syzygium cumini & Padal \\
Tamarindus indica & Jamun \\
Tamarix aphyalla & Imli \\
Tectona grandis & Pharash \\
Tecomella undulata & Saagwan \\
Terminalia arjuna & Rohida \\
T. bellirica & Arjun, hadod, kohada \\
Terminilia crenulata & Baheda \\
Wrightia tinctoria & Saja, Saadad \\
W. tomentosa & Khirani \\
Zizyphus mauritiana & Khirana, dudha \\
Z. xylopyrus & Ber \\
\hline
\end{tabular}

(2) Economy (3) Ecology. The scientists have recently found that a number of natural dye stuff and textile auxiliaries being used by the industry (Yadav, 1998).

Table 2. Natural dyes sources and related parts.

\begin{tabular}{lcc}
\hline Dye source & Parts used & Colour \\
\hline Harad & Fruit & Yellow \\
Neel & Leaves & Blue \\
Haldi & Rhizome & Light yellow to orange \\
Babool & Bark & Dark brown \\
Tesu/ palash & Flowers & Brilliant yellow \\
kattha & Wood & Brown, dark red \\
Phalsa & Fruit & Purple \\
Anar/naspal & Dry rind & Yellow, golden brown \\
Gulab & Flower & Red, pink \\
Kikar /jungle jalebi & Bark & Dark brown \\
Gajar & Root & Orange \\
Jor-tor & Bark & Brown \\
Harshingar & Flower & Orange, golden yellow \\
Gurhal & Flower & Pink, red \\
Dudhi & Leaves, seeds & Indigo blue \\
Amaltas & Flower & Yellow \\
Am, ambi & Bark & Yellow \\
Genda & Flower & Saffron yellow \\
Dhavde & Flower & Brown \\
Ratanjot & Root , leaves & Red and brown \\
Manjeeth & Roots & Red and orange \\
\hline
\end{tabular}

Consequently, synthetic dyestuffs have been criticized with a belief that "all natural things are good for life on the earth." In line with this trend, there is now an ever 
increasing lobby for using natural colouring matters for textile substrates (Lokhande et al., 1999).

On the basis of above discussion, researcher gives some suggestions to empower tribal women by utilizing and marketing of natural resources that can be used as dyes. No doubt, the state government and central agencies are giving them loans for supporting their economy, but in absence of sound income generating source, women are often unable to repay them. There have been a number of constraints which need to be duly addressed and remedial measures should be taken; so that the underutilized forest resources could be utilized in the socio- economic development of the tribal women in a sustainable manner.

I dentified constraints:

Inadequate appreciation of the role and value of forests by local residing tribal people and women.

Inadequate investment in forestry sector under the state and Government plan.

Inadequate income and employment generation programmes and perpetuating poverty.

Inadequate strengthening of institutional structure misguiding tribal people.

Insufficient inter-departmental co-ordination and networking among tribe communities, forest conservation committees, biodiversity research departments and marketing societies.

Insufficient motivation (low morale) of forestry personnel and lack of incentives and welfare measures. Inadequate involvement of Nongovernmental organizations (NGOs) to facilitate tribal people's participation.

Inadequate harnessing of science and technology inputs to enhance the production and conservation of forests. Inadequate institutional financing inputs through appropriate agency (Forest Corporation), many policies are paper based and ineffective on actual ground.

Tribal women are unaware about the potential uses of natural products; their knowledge is limited up to only collecting wood for fuel.

Inadequate transportation facility, collection methods, storage techniques, marketing and networking with buyers is difficult task for female tribes.

Unorganized and absence of unity in female tribes. Some beliefs like Dev Van Sarachan (conservation of trees nearby temple or religious place) are also loosing importance.

Involvement of beneficiaries at all level of planning and implementation is missed and neglected.

Textile industry and its relation with natural resources are not known to tribal female.

Self sufficiency system of ecology is not utilized by habitants of hilly tribes.

Industrialization, mobilization, falling forest area, increasing population density, unawareness, lack of scientific knowledge, lack of professionalism are basic constraints that need to be improved timely.

Besides so many constraints the big constraint is tribal female's low self esteem, their motivational level, their dedication to become the part of sustainable development, their efforts to earn profit, their commitment towards conservation of forests, their zeal to move forward in right direction is somewhat missing in young generation. To earn short term profit they are losing their natural possessions and treasure.

These are some serious constraints that need purposefully map work and guideline for empowering women.

\section{Conclusion}

In recent years, however, the situation has been considerable improving and attention on the production of natural products is also increasing. But yet many species of trees and plants have not been utilized to full potential in spite of their economic value.In order to ensure sustainable utilization of these less known resources, efforts are, therefore needed to conserve the valuable forests and also to standardise utilization and processing technologies for their use as dye source and other produce. Fortunately both national and international agencies have realized the need for strengthening these activities. The International Plant Genetic Resource Institute (IPGRI), Food and Agricultural organisation (FAO) of United Nations, the International Fund for Agricultural Research (IFAR) are some examples. Their emphasis is to promote and support activities on forest conservation and promoting livelihood practice. The future of these potential and valuable resources is great and would have enormous socioeconomic benefits. There is ample scope to utilize the available diversity of forest products, in turn, provide stability to the economy of the tribes living in hilly Arawali areas. Tribal communities form about $90 \%$ of the population, undertaking subsistence agriculture in the valleys. The active involvement of traditional users in the Village Forest Committees has not only helped prevent conflicts, but also contributed to the success of efforts in the regeneration of degraded forest and exploring avenues of sustainable livelihood patterns.

\section{REFERENCES}

MFR (2008). Glossary of Foresry Terms in British Columbia: Ministry of Forests and Range. .http:// www.for.gov.bc.ca/hfd/library/documents/glossary/ Glossary.pdf Retrieved on November 30, 2009.

Chauhan, N.K. (2008). Hydrogeology Assessment Report: Wakal River Basin, India. Global. Water for Sustainability Program, Florida International University. 13 pp.

Chouhan, V.L. (2007). Economic development and tribal women. Abstract Book, paper presented in Regional Seminar on Tribals and Family, MohanLal Sukhadia University, Udaipur. 
2 Feb; 9 pp.

DES. (2009). Facts about Rajasthan, Directorate of Economics and Statistics, Jaipur-2009. http://statistics.rajasthan.gov.in/ final_news_sep.pdf

EAMF. (2012). Environment assessment and management framework, Rajasthan Agriculture Competitiveness Project Report by Ministry of Agriculture. Government of Rajasthan, $38 \mathrm{pp}$.

Hegde, N. (2005). Development of non-timber forest product species for providing sustainable livelihood in India. International Workshop on Global Partnership on NonTimber F orest Products for Livelihood D evelopment (pp. D ecember 1-3). M orocco: International N etwork for Bamboo and Rattan (INBAR).

Jena, M. K. (2000). Forest and tribal sacred complex a comparision of three tribes of Orissa. In K. Seeland, \& F. Schmithusen, $M$ an in the Forest. New Delhi: D.K. Printworld (P) Ltd. 269-290 pp

Laxmi, V., Parikh, J., Karmakar, S. and Dabrase, P. (2003). Household energy, women's hardship and health impacts in rural Rajasthan. E nergy for Sustainable D evelopment, 8(1): 51-68.

Lokhande, H.T. and Dorugade, Vishnu A. (1999). Dyeing nylon with natural dyes. A merican D yestuff Reporter, 88 (2): 29-34.

Mogra D. (1999). Optimization of dyeing using naspal rind on wool. M.Sc. unpublished Thesis, Dept. of Textile and Apparel Designing, Rajasthan Agriculture University, Bikaner. 62 pp.

Moran, E. (2005). Human-environment interactions in forest ecosystems: An introduction. In E. F. Moran and E. Ostrom. Seeing the F orest and the Tree L ondon, England: The MIT Press, 3-22 pp.

NAIP, (2010-11). National agricultural innovation project research achievements and innovations: Component 2, Indian Council of Agricultural Research (ICAR). 21 pp.
Pokharna, V. (1997). Growth performance of tourism in Rajasthan and its sustainability. Sustainable development in tribal and backward areas, Indus Publishing Company, New Delhi, 136 pp.

RAMB, (2012). The Rajasthan State Agricultural Marketing Board, http://www.rsamb.rajasthan.gov.in/Rajasthan.htm Retrieved on 25 April, 2011.

Ray, S. (2008). Management of natural resources-Institutions for Sustainable Livelihood: The Case of Rajasthan. New Delhi: Academic Foundation,

Robbins, P., McSweeney, K., Chhangani, A. K., Rice, J. L., Fachinger, P. and Nell, W. (2009). Conservation as it is Illicit resource use in a Wildlife reserve in India. Human Ecology, 37 (5): 559-575.

Schmithusen, F. Seeland, Klaus, (2000). Schmithusen, Franz. In T. S.-C. Practices, Man in The F orest, New Delhi: D.K. Printworld (P) Ltd, 11-22 pp.

Shrivastava, M. (2006). Annual Report, Technical bulletin on natural dyes: Their availability and utilization in different states of All India Coordinated Research Project, ICAR, Department of Clothing and Textile, College of Home Science, MPUAT, Udaipur, Rajasthan. 124-126 pp.

Tejaswi, P. B. (2008). Non Timber Forest Products (NTFPs) for Food and Livelidood security, An Economic Study of Tribal Economy in Western Ghata of Karnataka, India. Unpublished Thesis. Ghent University, Belgium.

Upadhyay, R. and Choudhary, M.S. (2012). Study of some common plants for natural dyes. International J ournal of Pharmaceutical Research and Bio-Science, 1(5):309-316.

Vyas, V. (2008). Status of implementation of the Forests Rights Act in Rajasthan workshop report on operationalisation of forest rights act. Capitalisation of livestock programme experiences India. New Delhi and Seva Mandir. pp. 25-32. Yadav, V.G. (1998). Dyes for the next Millennium. Colourage, January, 45:53-54. 